\title{
FISH FUNCTIONAL GROUP DIVERSITY AND ANALYSIS OF INFLUENCING FACTORS IN THE MULING RIVER BASIN IN NORTHEAST CHINA
}

\author{
SUN, X. ${ }^{1,2 \#}-$ CHAI, Y. H. ${ }^{3 \#}-$ WANG, Y. ${ }^{1,2}-$ YU, H. X. ${ }^{4}-$ CHAI, F. Y. $.^{*}-$ WANG, W..$^{1,2^{*}}$ \\ ${ }^{1}$ College of Fisheries and Life Science, Dalian Ocean University, Dalian 116023, China
}

${ }^{2}$ Key Laboratory of Applied Biology and aquaculture of northern fishes in Liaoning Province, Dalian 116023, China

${ }^{3}$ Aulin College, Northeast Forestry University, Harbin 150020, China

${ }^{4}$ College of Wildlife and Protected Area, Northeast Forestry University, Harbin 150040, China

${ }^{5}$ School of Management, Heilongjiang University of Science and Technology, Harbin 150020, China

${ }^{\#}$ Co-first authors

These authors contributed to the work equally.

${ }^{*}$ Corresponding authors

e-mail: chaifangying@126.com (Chai, F.Y.);wangwei@dlou.edu.cn (Wang,W.)

(Received 6 Jul 2021; accepted 20 ${ }^{\text {th }}$ Sep 2021)

\begin{abstract}
In order to understand fish fauna in the Muling river in Northeast China, an experiment was carried out in May, July and October 2015. This survey set up 28 sampling sites where 348 fishes were identified in total belonging to 4 orders, 5 families, and 22 species. The dominant species were Cobitis granoci, Rostrogobio amurensisi, Cobitis lutheri, Pseudorasbora parva, Phoxinus lagowskii, Perccottus glehni, Carassius auratus gibelio, Aristichthys nobilis in the Muling River basin. The diversity of species was analysed by the Shannon-Weaver and Pielou methods, which indicated few differences between sampling site of these two methods. Muling River showed an average Shannon-Weaver index of 1.97, an average Pielou index of 0.36 , and an average Maralef index of 1.16. According to feeding habits, catchment fishes of the Muling river were divided into 7 functional groups: herbivores, insectivores, phytoplanktivore, zooplanktivores, benthivores, omnivores, piscivores. Canonical Correlation Analysis (CCA) found that, water environmental factors influencing fish functional groups varied between different seasons. In spring, the factors were total nitrogen (TN), oxidation-reduction potential (ORP), pH value $(\mathrm{pH})$, water transparency $(\mathrm{SD})$, conductivity (COND). In summer, the factors were total nitrogen $(\mathrm{TN})$, oxidation-reduction potential (ORP), $\mathrm{pH}$ value $(\mathrm{pH})$, dissolved iron $(\mathrm{Fe})$, water temperature (WT), total dissolved solids (TD). In autumn, the factors were the same as that of in summer.
\end{abstract}

Keywords: fish, freshwater, wetland, correlation, environmental variables

\section{Introduction}

Fish has an important position in the aquatic ecosystem, which distributed in various water bodies around the world (Holmlund and Hammer, 1999). Fish is the most biologically diverse group of vertebrates, accounting for more than half of the number of vertebrate species on Earth, and $40 \%$ of fish live in freshwater. There are nearly 1,000 species of freshwater fishes in China, which are widely distributed in major water systems in our country. In the process of the evolution of various organisms, fish have gradually acquired more and more extensive habitats, which promotes them to have a 
variety of physiological and ecological characteristics. Since the 1990s, countries around the world have gradually realized the importance of fish resource management. The continuous development of high technology such as fish investigation and monitoring, sustainable development and utilization of fish resources, and fishery product processing has improved water protection. The environment and fish species diversity have been recognized by major countries with fisheries (Wang et al., 2006). Moreover, because of the important economic position of fisheries in human society, when fish ecology research came out, it has achieved rapid development. Its scientific research results can not only provide scientific basis for water environment assessment and fish resource development and utilization, but also provide scientific basis for fish protection and aquatic product production.

Humans can use the characteristics of fish to adapt to water bodies and regard them as a type of indicator organisms when evaluating the health of river ecosystems (Karr, 1981). It is used to diagnose the degree of accumulation of chemical, physical and biological pollutants in the water body, thereby reflecting the quality of the water environment (Simon, 1999). In addition, as a tool for evaluating and monitoring water quality, fish has many unique conveniences. With a long life history, acceptance and long-term effects of biological conditions, it has a wider habitat range compared with smaller plankton and benthic animals, thus possesses a certain versatility. As an evaluation element, fish have larger biological individuals, which are more intuitive and easy to identify and identify during monitoring, and fish classification work is relatively complete, and the relevant scientific research results are accumulated, which makes the fish easy to capture and the data easy to measure and analyze (Xia et al., 2009). Biodiversity not only reflects the diversification and variability of organisms and the complexity of the ecological conditions of species habitats, it also reflects the diversity of biological organisms on Earth (Ma, 1994). Fish are important indicators of the water environment. Fish occupy an important position in the ecosystem. In recent years, human activities have had a huge impact on fish diversity, leading to the decline of species diversity, endangerment and extinction of species, miniaturization of fish, and changes to the structure and function of aquatic ecosystems (Chen, 1990; Sarkar et al., 2012). Regarding the above issues related to fish diversity, humans use different targeted survey methods to monitor different water bodies. The "Handbook of Biodiversity Methods" (Giles et al., 2005) has detailed and specific descriptions of fish monitoring methods. These methods include traditional fishing gear, such as gill nets (Yang, 2012), trawl nets (Mao et al., 2016), various trapping nets including fixed nets (Shi et al., 2015), ground cages, shrimp cages (Xiao et al., 2015), etc., as well as modern fish hunters. Under different water environment conditions, hydroacoustic equipment such as instrument can be used as a reference when used for different purposes (Liu et al., 2016). The rational use of fishing tools can not only improve the ecological environment and contribute to scientific research, but also promote the harmonious coexistence of humans and organisms (Chen, 2014).

In the history of the Muling River basin, fishery resources were very rich. The ancestors mostly lived on fishing. However, due to overfishing and environmental pollution and other factors, fishery resources have declined sharply in the past 30 years. With the intensification of human activities and the construction of water conservancy projects, the ecological environment of Muling River has undergone tremendous changes, and the structure of fish communities has also changed. In this study, by monitoring the fish diversity of the Muling River basin and measuring the water quality, 
the status of fish resources was investigated and monitored, and the factors affecting the diversity of fish species were found. The evaluation provides a scientific basis for the restoration of fish diversity and watershed management in the Muling River bBasin.

\section{Materials and methods}

\section{Study area}

Muling River has a total length of $834 \mathrm{~km}$ and a drainage area of $18427 \mathrm{~km}^{2}$. It is the largest tributary on the left bank of the Wusuli River, a border river in the northeast of China. The Muling River Basin belongs to the temperate semi-humid monsoon climate. The annual average temperature is $3.2^{\circ} \mathrm{C}$, the average temperature in January is $-19^{\circ} \mathrm{C}$, the average temperature in July is $21.3^{\circ} \mathrm{C}$, the average annual precipitation is $532 \mathrm{~mm}$, and the frost-free period is $148 \mathrm{~d}$. The Muling River is a mountainous river with a total river drop of $699 \mathrm{~m}$ and an average annual runoff of 2.35 billion $\mathrm{m}^{3}$. It is rich in hydropower resources.

The Muling River Basin is divided into upper, middle and lower reaches according to geographical location. Most areas in the upper reaches of the mountain are mountainous and have a temperate continental climate. The winter is not only long and cold, but the summer is short but dry. The annual average rainfall is $531 \mathrm{~mm}$. The rainfall is mostly in July, August and September. Floods mostly occur in late June and July and August. The upstream is not only the center of heavy rain, but also the source of flooding. The middle reaches are located in Mishan City, with the Wanda Mountains in the north, the Changbai Mountains in the south, and the Muling River alluvial plain in the middle, with Xingkai Lake, which is the largest boundary lake in the country. The downstream is located in the border city of Northeast China-Hulin City, located at the southern foot of Wanda Mountain, in the Muling River-Xingkai Lake Plain Area of the Sanjiang Plain. It belongs to a temperate continental monsoon climate, and it is a mild and humid climate zone in the Sanjiang Plain.

\section{Field sampling and laboratory analysis}

In May, July and October 2015, a three-season fish sampling survey was conducted in the Muling River basin. According to the characteristics of fish distribution, a total of 28 sampling sites were set up from upstream, midstream to downstream. Three parallels were set for each sampling sites (Fig. 1, Table 1).

The survey method is in accordance with the principles and requirements of the "Inland Water Fishery Natural Resources Survey Manual" (Zhang and He, 1993), and the identification of fish samples refers to the "Heilongjiang Province Fish History" (Zhang, 1995). Gillnet (40 m, 3-7 cm mesh) and electric fish device (2000W, 650V) for fish specimen collection. Some fish species cannot be accurately identified at the scene, and the specimens are marked, photographed and kept on file, and taken back to the laboratory for further processing. While sampling, local residents and fishermen were visited to learn more about the current status of the Muling River fish resources.

According to the requirements of "Water and Wastewater Monitoring Method" (Fourth Edition) (MEP, 2002) and the needs of on-site investigation, the following environmental factors are measured: conductivity (COND), dissolved oxygen (DO), $\mathrm{pH}$ value $(\mathrm{pH})$, water temperature (WT), oxidation-reduction potential (ORP), total nitrogen (TN), total phosphorus (TP), total dissolved solids (TD), nitrate nitrogen $\left(\mathrm{NO}_{2}-\mathrm{N}\right)$, 
ammonium nitrogen $\left(\mathrm{NH}_{4}-\mathrm{N}\right)$, nitrate $\left(\mathrm{NO}_{3}-\mathrm{N}\right)$, chemical oxygen demand (COD), dissolved iron $(\mathrm{Fe})$ and dissolved copper $(\mathrm{Cu})$ and water transparency $(\mathrm{SD})$.
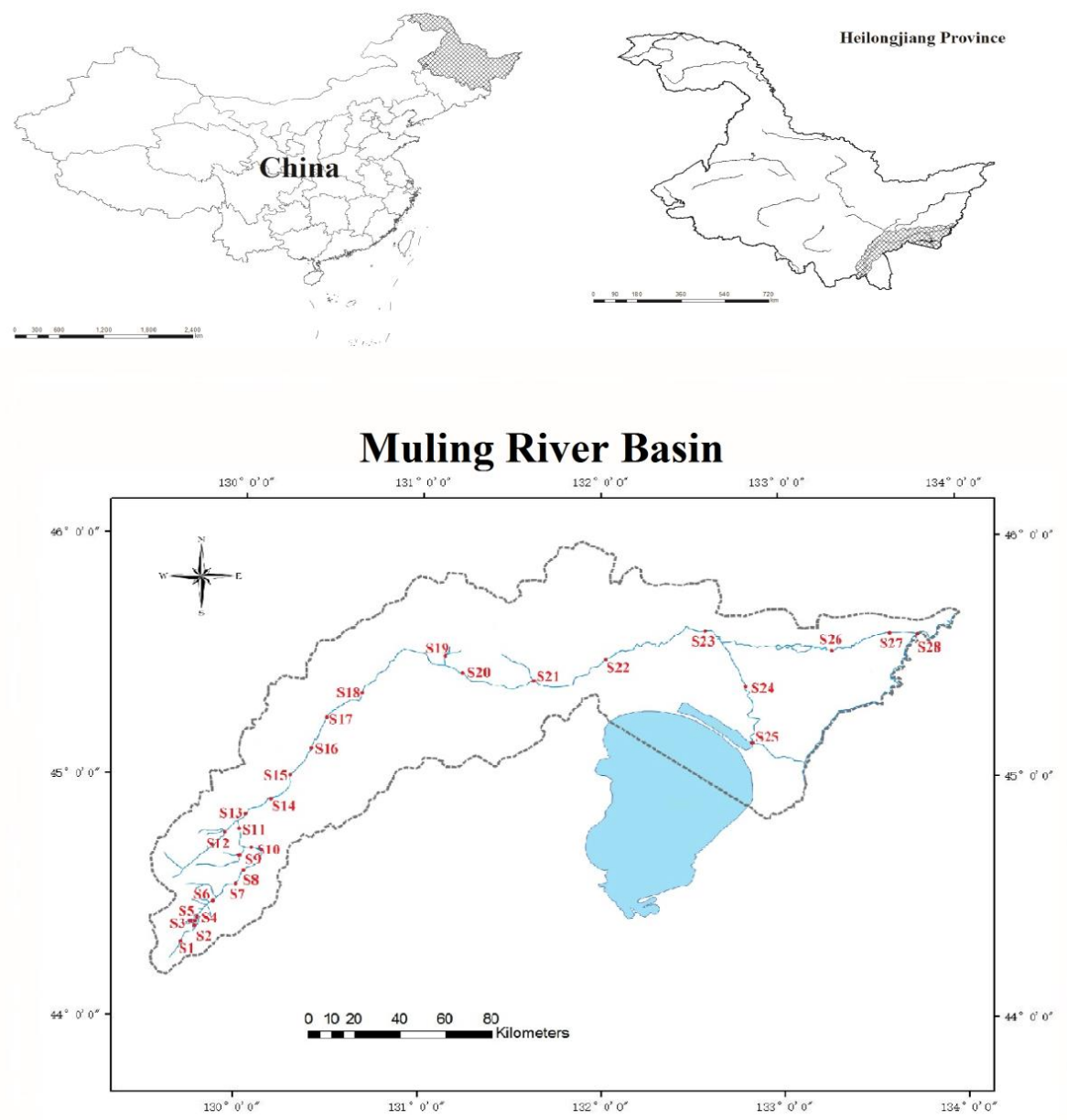

Figure 1. Location of sampling sites in the Muling River basin

Table 1. The sampling stations and coordinates in the Muling River basin

\begin{tabular}{c|c|c|c}
\hline Sampling sites & Coordination & Sampling sites & Coordination \\
\hline S1 & $44^{\circ} 01^{\prime} 48^{\prime \prime} \mathrm{N}, 130^{\circ} 11^{\prime} 24^{\prime \prime} \mathrm{E}$ & $\mathrm{S} 15$ & $44^{\circ} 40^{\prime} 12^{\prime \prime} \mathrm{N}, 130^{\circ} 26^{\prime} 24^{\prime \prime} \mathrm{E}$ \\
S2 & $44^{\circ} 03^{\prime} 36^{\prime \prime} \mathrm{N}, 130^{\circ} 10^{\prime} 48^{\prime \prime} \mathrm{E}$ & $\mathrm{S} 16$ & $44^{\circ} 53^{\prime} 24^{\prime \prime} \mathrm{N}, 130^{\circ} 30^{\prime} 36^{\prime \prime} \mathrm{E}$ \\
S3 & $44^{\circ} 03^{\prime} 00^{\prime \prime} \mathrm{N}, 130^{\circ} 09^{\prime} 36^{\prime \prime} \mathrm{E}$ & $\mathrm{S} 17$ & $45^{\circ} 00^{\prime} 00^{\prime \prime} \mathrm{N}, 130^{\circ} 32^{\prime} 24^{\prime \prime} \mathrm{E}$ \\
S4 & $44^{\circ} 04^{\prime} 12^{\prime \prime} \mathrm{N}, 130^{\circ} 10^{\prime} 48^{\prime \prime} \mathrm{E}$ & $\mathrm{S} 18$ & $45^{\circ} 04^{\prime} 48^{\prime \prime} \mathrm{N}, 130^{\circ} 40^{\prime} 12^{\prime \prime} \mathrm{E}$ \\
S5 & $44^{\circ} 04^{\prime} 48^{\prime \prime} \mathrm{N}, 130^{\circ} 10^{\prime} 48^{\prime \prime} \mathrm{E}$ & $\mathrm{S} 19$ & $45^{\circ} 18^{\prime} 00^{\prime \prime} \mathrm{N}, 131^{\circ} 00^{\prime} 36^{\prime \prime} \mathrm{E}$ \\
S6 & $44^{\circ} 11^{\prime} 24^{\prime \prime} \mathrm{N}, 130^{\circ} 15^{\prime} 36^{\prime \prime} \mathrm{E}$ & $\mathrm{S} 20$ & $45^{\circ} 18^{\prime} 00^{\prime \prime} \mathrm{N}, 131^{\circ} 03^{\prime} 36^{\prime \prime} \mathrm{E}$ \\
S7 & $44^{\circ} 13^{\prime} 12^{\prime \prime} \mathrm{N}, 130^{\circ} 15^{\prime} 00^{\prime \prime} \mathrm{E}$ & $\mathrm{S} 21$ & $45^{\circ} 20^{\prime} 24^{\prime \prime} \mathrm{N}, 131^{\circ} 31^{\prime} 48^{\prime \prime} \mathrm{E}$ \\
S8 & $44^{\circ} 13^{\prime} 48^{\prime \prime} \mathrm{N}, 130^{\circ} 15^{\prime} 36^{\prime \prime} \mathrm{E}$ & $\mathrm{S} 22$ & $45^{\circ} 27^{\prime} 00^{\prime \prime} \mathrm{N}, 131^{\circ} 52^{\prime} 12^{\prime \prime} \mathrm{E}$ \\
S9 & $44^{\circ} 21^{\prime} 36^{\prime \prime} \mathrm{N}, 130^{\circ} 16^{\prime} 48^{\prime \prime} \mathrm{E}$ & $\mathrm{S} 23$ & $45^{\circ} 42^{\prime} 00^{\prime \prime} \mathrm{N}, 132^{\circ} 25^{\prime} 12^{\prime \prime} \mathrm{E}$ \\
S10 & $44^{\circ} 24^{\prime} 36^{\prime \prime} \mathrm{N}, 130^{\circ} 19^{\prime} 12^{\prime \prime} \mathrm{E}$ & $\mathrm{S} 24$ & $45^{\circ} 35^{\prime} 24^{\prime \prime} \mathrm{N}, 132^{\circ} 36^{\prime} 36^{\prime \prime} \mathrm{E}$ \\
S11 & $44^{\circ} 28^{\prime} 12^{\prime \prime} \mathrm{N}, 130^{\circ} 14^{\prime} 24^{\prime \prime} \mathrm{E}$ & $\mathrm{S} 25$ & $45^{\circ} 19^{\prime} 48^{\prime \prime} \mathrm{N}, 132^{\circ} 48^{\prime} 36^{\prime \prime} \mathrm{E}$ \\
S12 & $44^{\circ} 28^{\prime} 12^{\prime \prime} \mathrm{N}, 130^{\circ} 12^{\prime} 36^{\prime \prime} \mathrm{E}$ & $\mathrm{S} 26$ & $45^{\circ} 44^{\prime} 24^{\prime \prime} \mathrm{N}, 132^{\circ} 57^{\prime} 00^{\prime \prime} \mathrm{E}$ \\
S13 & $44^{\circ} 29^{\prime} 24^{\prime \prime} \mathrm{N}, 130^{\circ} 13^{\prime} 48^{\prime \prime} \mathrm{E}$ & $\mathrm{S} 27$ & $45^{\circ} 45^{\prime} 36^{\prime \prime} \mathrm{N}, 133^{\circ} 06^{\prime} 00^{\prime \prime} \mathrm{E}$ \\
S14 & $44^{\circ} 34^{\prime} 48^{\prime \prime} \mathrm{N}, 130^{\circ} 19^{\prime} 48^{\prime \prime} \mathrm{E}$ & $\mathrm{S} 28$ & $45^{\circ} 58^{\prime} 12^{\prime \prime} \mathrm{N}, 133^{\circ} 40^{\prime} 12^{\prime \prime} \mathrm{E}$ \\
\hline
\end{tabular}




\section{Data analysis}

For data analysis the following indices were calculated:

Pinkas index $(I R I)$ :

$$
I R I=(N \%+W \%) \times F \%
$$

where, $N \%$ is the percentage of a certain fish's tail to the total, $W \%$ is the percentage of a certain fish's mass to the total mass, $F \%$ is the percentage of the number of sampling points that a certain fish appears in the total number of sampling sites.

Shannon-Weaver index $\left(H^{\prime}\right)$ :

$$
H^{\prime}=-\sum_{i=1}^{s} P_{i} \log _{2} P_{i}
$$

where, $P_{i}$ is the percentage of the total number of $i$-th individuals to the total number of individuals.

Pielou index $\left(J^{\prime}\right)$ :

$$
J^{\prime}=H^{\prime} / \ln S
$$

where, $H^{\prime}$ is the Shannon-Wiener index, and $S$ is the total number of species.

Margalef index $(D)$ :

$$
D=\frac{S-1}{\ln N}
$$

where, $S$ is the total number of species, and $N$ is the total number of all individuals.

For the correlation analysis of fish functional groups in Muling River, CANOCO 4.5 software is used to perform canonical correspondence analysis (referred to as CCA analysis) on fish species data and water environmental factor data. Before the analysis, in order to reduce the influence of extreme data, each data matrix (except $\mathrm{pH}$ value) is transformed by $\lg (\mathrm{x}+1)$, and the sorting result is represented by a double sequence graph.

\section{Results}

\section{Environmental factors}

The seasonal variations of environmental factors (mean \pm standard error) values among the sampling sites in different seasons were presented in Fig. 2. We found that $\mathrm{COND}, \mathrm{pH}, \mathrm{NO}_{2}-\mathrm{N}, \mathrm{COD}_{\mathrm{Mn}}$ and $\mathrm{SD}$ showed the lowest values in summer. On the contrary, DO, WT, ORP, TN, TP, $\mathrm{NH}_{4}-\mathrm{N}, \mathrm{NO} 3-\mathrm{N}, \mathrm{Fe}$ and $\mathrm{Cu}$ showed the highest values in the same season. TD showing a continuous growth trend, and $\mathrm{COD}_{\mathrm{Mn}}$ seasonal variation fluctuates little.

\section{Fish community structure}

A total of 348 individual catchment fish belongs to 4 orders, 5 families, 16 genera, 22 species (Table 2). The Cypriniformes are the most numerous, with 19 species 
(86.36\%), and each of the remaining three orders (4.55\%). At the family level, Cyprinids are also the most numerous, with 14 species $(63.64 \%)$, followed by Loach, with 5 species $(22.73 \%)$, Lamprey, Siluriaceae, and Channaidae family containing only one species each, accounting for $4.55 \%$ each.
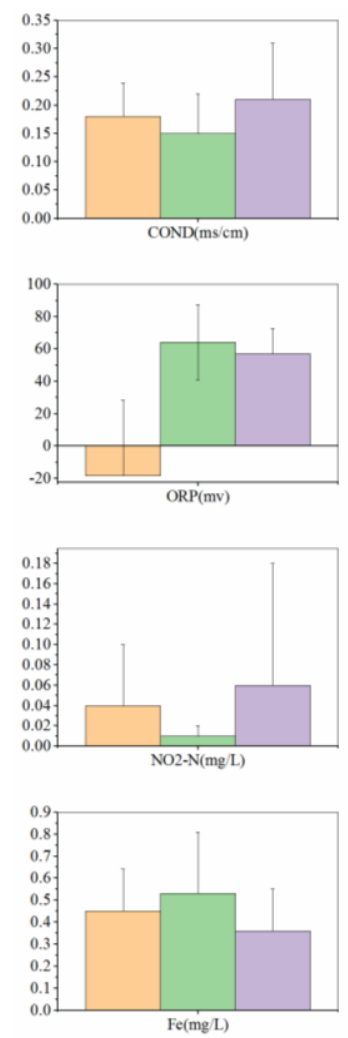
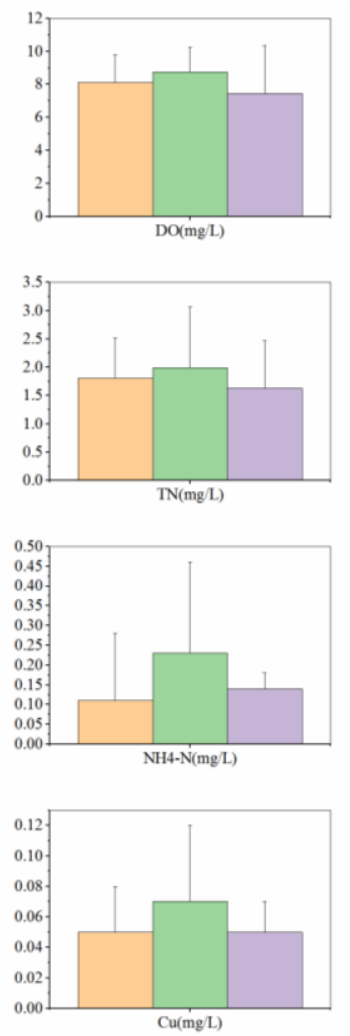
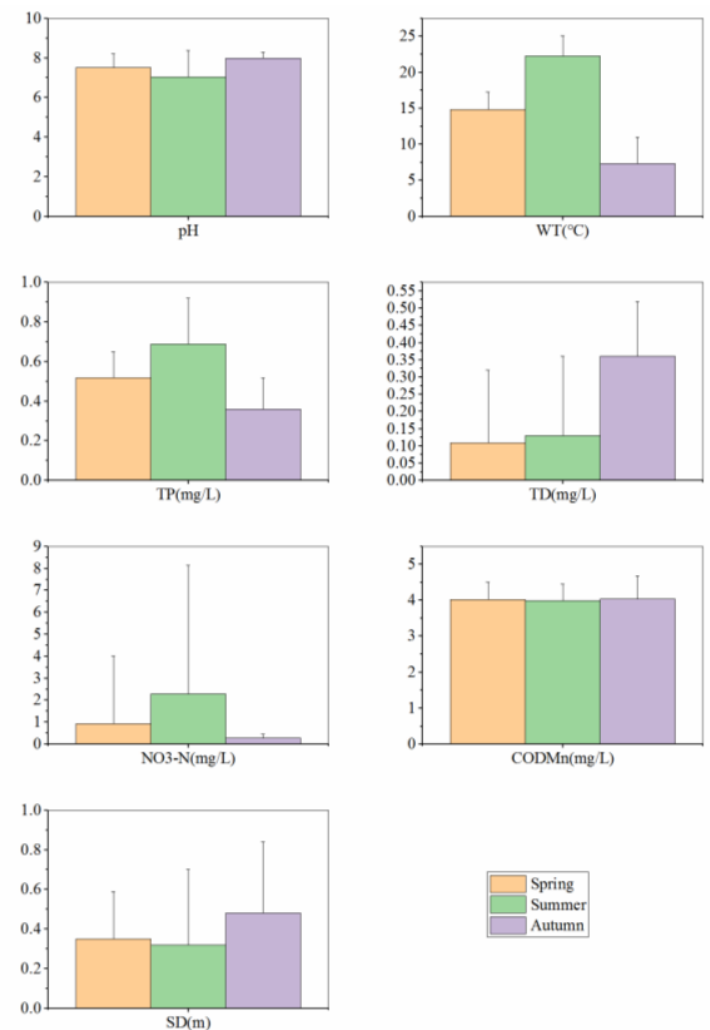

Figure 2. The seasonal variations of environmental factors (means \pm standard error): conductivity (COND), dissolved oxygen (DO), $p H$ value $(p H)$, water temperature (WT), oxidation-reduction potential (ORP), total nitrogen (TN), total phosphorus $(T P)$, total dissolved solids (TD), nitrate nitrogen $\left(\mathrm{NO}_{2}-\mathrm{N}\right)$, ammonium nitrogen $\left(\mathrm{NH}_{4}-\mathrm{N}\right)$, nitrate $\left(\mathrm{NO}_{3}-\mathrm{N}\right)$, chemical oxygen demand $\left(C O D_{M n}\right)$, dissolved iron $(\mathrm{Fe})$ and dissolved copper $(\mathrm{Cu})$ and water transparency $(S D)$

\section{Variation of fish diversity index}

The annual mean of Shannon-Weaver index is 1.97 (Fig. 3) in the Muling River Basin, the mean of Pielou index is 2.94 (Fig. 4), and the mean of Maralef index is 1.16 (Fig. 5). The three indices fluctuate little with the seasons throughout the year, and their changing trends are roughly the same. This shows that the fish species in the Muling River Basin are relatively stable.

In spring, the mean of Shannon-Weaver index at each sampling site is 1.92 , and the fluctuation range is $0.7 \sim 3.99$, the mean of Pielou index is 0.36 , and the fluctuation range is $0.16 \sim 0.8$, the mean of Maralef index is 1.14, the fluctuation range is 0.28 2.68.

In summer, the mean of Shannon-Weaver index at each sampling site is 2.02, and the fluctuation range is $0.92 \sim 4.02$, the mean of Pielou index is 0.37 , and the fluctuation range is $0.2 \sim 0.58$, the mean of Maralef index is 1.16, the fluctuation range is $0.35 \sim 2.75$. 
In autumn, the mean of Shannon-Weaver index at each sampling site is 1.97, and the fluctuation range is $0.70 \sim 4.09$, the mean of Pielou index is 0.36 , and the fluctuation range is $0.17 \sim 0.55$, the mean of Maralef index is 1.18 , the fluctuation range is $0.49 \sim 2.83$.

Table 2. List of catchment fish of Muling River basin

\begin{tabular}{|c|c|c|c|c|}
\hline Order & Family & Genus & Species & IRI \\
\hline \multirow[t]{19}{*}{ Cypriniformes } & Cyprinidae & Ctenopharyngodon & Ctenopharyngodon idellus & 45.76 \\
\hline & & Phoxinus & Phoxinus phoxinus & 7.2 \\
\hline & & & Phoxinus percnurus & 69.55 \\
\hline & & & Phoxinus czekanowskii & 52.91 \\
\hline & & & Phoxinus lagowskii & 9 \\
\hline & & Hemiculter & Hemiculter leucisclus & 187.95 \\
\hline & & Pseudorasbora & Pseudorasbora parva & 19.88 \\
\hline & & Abbottina & Abbottina rivularis & 241.65 \\
\hline & & Rostrogobio & Rostrogobio amurensisi & 31.95 \\
\hline & & Saurogobio & Saurogobio dabryi & 326.04 \\
\hline & & Cyprinus & Cyprinus carpio haematopterus & 4.32 \\
\hline & & Carassius & Carassius auratus gibelio & 84.24 \\
\hline & & Aristichthys & Aristichthys nobilis & 151.94 \\
\hline & & Hypophthalmichthys & Hypophthalmichthys molitrix & 133.92 \\
\hline & Cobitidae & Lefua & Lefua costata & 46.08 \\
\hline & & Cobitis & Cobitis lutheri & 24.65 \\
\hline & & & Cobitis granoci & 256.8 \\
\hline & & Misgurnus & Misgurnus mohoity & 831.39 \\
\hline & & & Misgurnus bipartitus & 67.21 \\
\hline Petromyzoniformes & Petromyzonidae & Lampetra & Lampetra reissneri & 53.25 \\
\hline Siluriformes & Siluridae & Silurus & Silurus asotus & 97.5 \\
\hline Perciformes & Eleotridae & Perccottus & Perccottus glehni & 136.04 \\
\hline
\end{tabular}

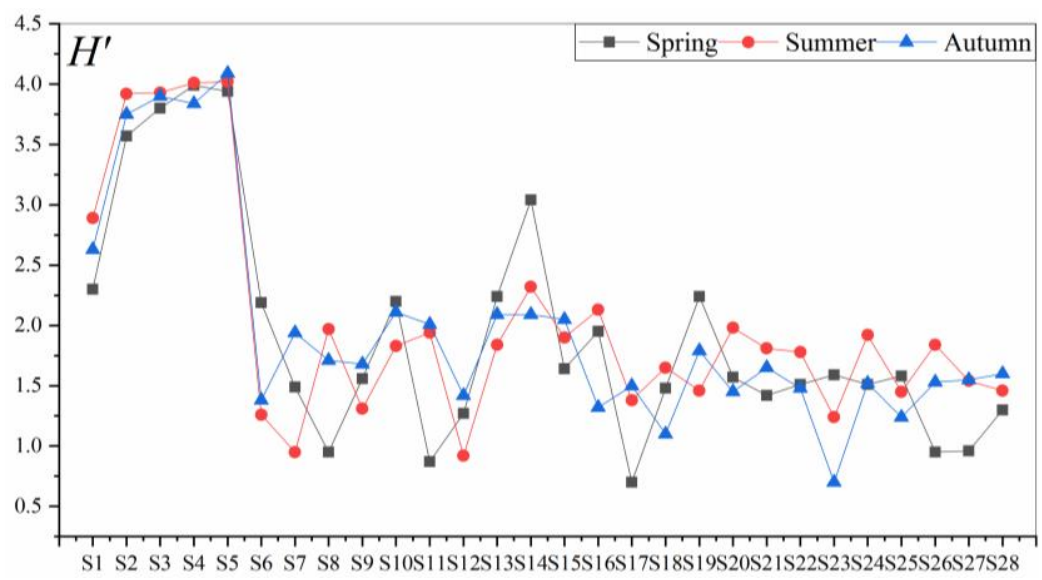

Figure 3. Shannon-Weaver index (H') of different sampling sites 


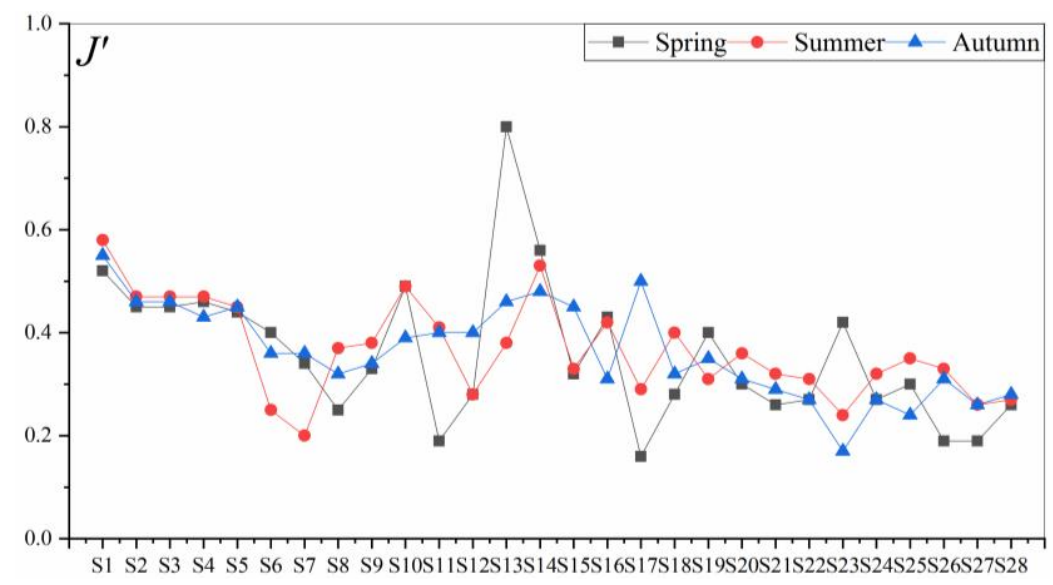

Figure 4. Pielou index ( $\left.J^{\prime}\right)$ of different sampling sites

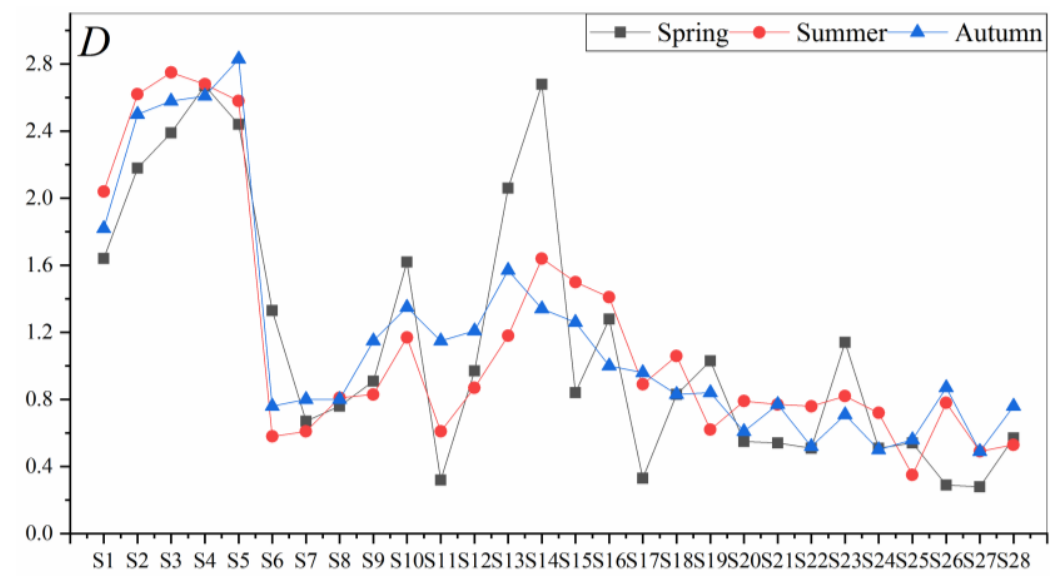

Figure 5. Margalef index $(D)$ of different sampling sites

\section{Correlation analysis of fish functional groups and water environment factors}

According to the food habit of the fish caught in the Muling River, especially the omnivorous fish, it is further refined according to the main source of food. For fish that do not have clear references to determine their feeding habits, they are inferred based on their close relatives and the structure of their feeding organs (Ding and Liu, 2011). The fish caught in the Muling River are mainly divided into seven types of functional groups: aquatic plant feeding (herbivores), aquatic insect feeding (insectivores), phytoplankton feeding (phytoplanktivores), zooplankton feeding (zooplanktivores), benthic animal feeding habits (benthivores), omnivores (omnivores), and carnivorous (piscivores). The coding of each functional group is shown in Table 3, and the data of different seasons and environmental factors of the catch were analyzed by Canonical Correlation Analysis (CCA) in CANOCO for Windows 4.5 software.

In spring (Fig. 6), pH, TD, WT, DO negatively correlated with axis $1, \mathrm{NH}_{4}-\mathrm{N}, \mathrm{NO}_{2-}$ $\mathrm{N}, \mathrm{Cu}$ positively correlated with axis 1 . SD negatively correlated with axis 2 , TN, ORP, $\mathrm{COND}, \mathrm{Fe}, \mathrm{TP}, \mathrm{NO}_{3}-\mathrm{N}$, and $\mathrm{COD}$ positively correlated with axis $2, \mathrm{NO}_{3}-\mathrm{N}, \mathrm{COD}$, and DO relatively weakly correlated. From the perspective of vector length, SD, pH, TN, ORP, and COND are the environmental factors that mainly affect the functional groups 
of the Muling River fish in spring. Function group FG1, FG2, FG3, and FG4 are distributed on the left side of axis 1 and below axis 2, and are mainly affected by hydrological factors ( $\mathrm{SD}, \mathrm{pH}, \mathrm{TD}, \mathrm{WT}$ ). FG5 is distributed on the right side of axis 1 , which is mainly affected by the concentration of nutrients $\left(\mathrm{NH}_{4}-\mathrm{N}, \mathrm{NO}_{2}-\mathrm{N}, \mathrm{TN}, \mathrm{TP}\right)$ and hydrological factors (COND, ORP). FG7 is mainly affected by $\mathrm{Cu}$ and FG6 is not greatly affected by water environmental factors.

Table 3. Catchment fish functional group composition and codes in Muling River basin

\begin{tabular}{c|c|c}
\hline Codes & FGs & Catchment \\
\hline FG1 & herbivores & Ctenopharyngodon idellus, Phoxinus phoxinus, Phoxinus lagowskii \\
FG2 & insectivores & Phoxinus percnurus, Lefua costata, Misgurnus bipartitus \\
FG3 & phytoplanktivores & Phoxinus czekanowskii, Rostrogobio amurensisi, Hypophthalmichthys \\
FG4 & zooplanktivores & molitrix \\
FG5 & benthivores & Aristichthys nobilis \\
FG6 & omnivores & Saurogobio dabryi, Cobitis lutheri, Cobitis granoci, Misgurnus mohoity \\
FG7 & piscivores & Cyprinus carpio haematopterus, Carassius auratus gibelio \\
\hline
\end{tabular}

Fish functional groups: aquatic plant feeding (FG1, herbivores), aquatic insect feeding (FG2, insectivores), phytoplankton feeding (FG3, phytoplanktivores), zooplankton feeding (FG4, zooplanktivores), benthic animal feeding habits (FG5, benthivores), omnivores (FG6, omnivores), carnivorous (FG7, piscivores)

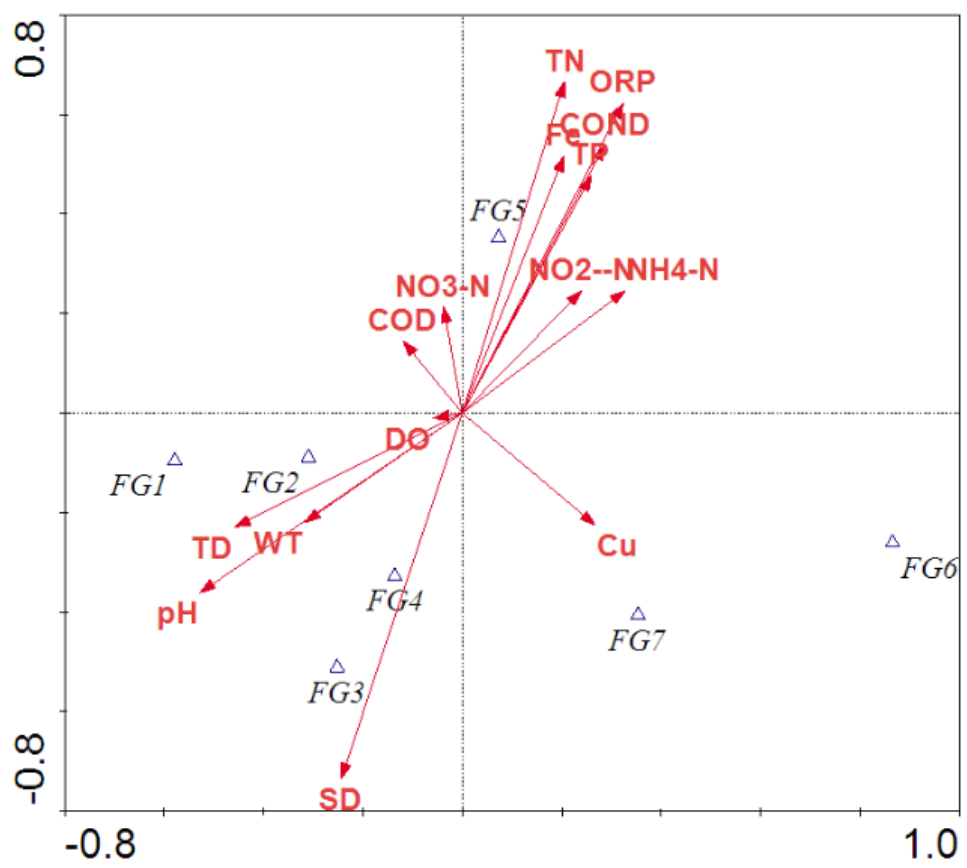

Figure 6. CCA tri-plot of fish functional groups and environmental factors in spring.

Environmental factors: conductivity (COND), dissolved oxygen (DO), $\mathrm{pH}$ value ( $\mathrm{pH})$, water temperature (WT), oxidation-reduction potential (ORP), total nitrogen (TN), total phosphorus $(T P)$, total dissolved solids $(T D)$, nitrate nitrogen $\left(\mathrm{NO}_{2}-\mathrm{N}\right)$, ammonium nitrogen $\left(\mathrm{NH}_{4}-\mathrm{N}\right)$, nitrate $\left(\mathrm{NO}_{3}-\mathrm{N}\right)$, chemical oxygen demand $(\mathrm{COD})$, dissolved iron $(\mathrm{Fe})$ and dissolved copper $(\mathrm{Cu})$ and water transparency (SD). Fish functional group: herbivores (FG1), insectivores (FG2), phytoplanktivores (FG3), zooplanktivores (FG4), benthivores (FG5), omnivores (FG6), piscivores (FG7) 
In summer (Fig. 7), $\mathrm{Cu}$ and SD negatively correlated with axis 1 , while $\mathrm{COD}, \mathrm{NO}_{3}-\mathrm{N}$, ORP positively correlated with axis 1 . Meanwhile, TD and $\mathrm{pH}$ negatively correlated with axis 2, while TN, WT, Fe, DO, COND, $\mathrm{NO}_{2}-\mathrm{N}, \mathrm{TP}, \mathrm{NH}_{4}-\mathrm{N}$ positively correlated with axis 2. The correlation between $\mathrm{COD}, \mathrm{NO}_{3}-\mathrm{N}, \mathrm{TP}, \mathrm{NO}_{2}-\mathrm{N}, \mathrm{NH}_{4}-\mathrm{N}, \mathrm{SD}$, and $\mathrm{Cu}$ was weak. From the perspective of vector length, TN, Fe, WT, ORP, TD, and pH are the environmental factors that mainly affect the functional groups of the Muling River fish in summer. Functional group FG3 and FG6 are distributed on the left side of axis 1 and below axis 2, and are mainly affected by hydrological factors (hardness, $\mathrm{pH}$ ), other functional groups are less affected by water environment factors.

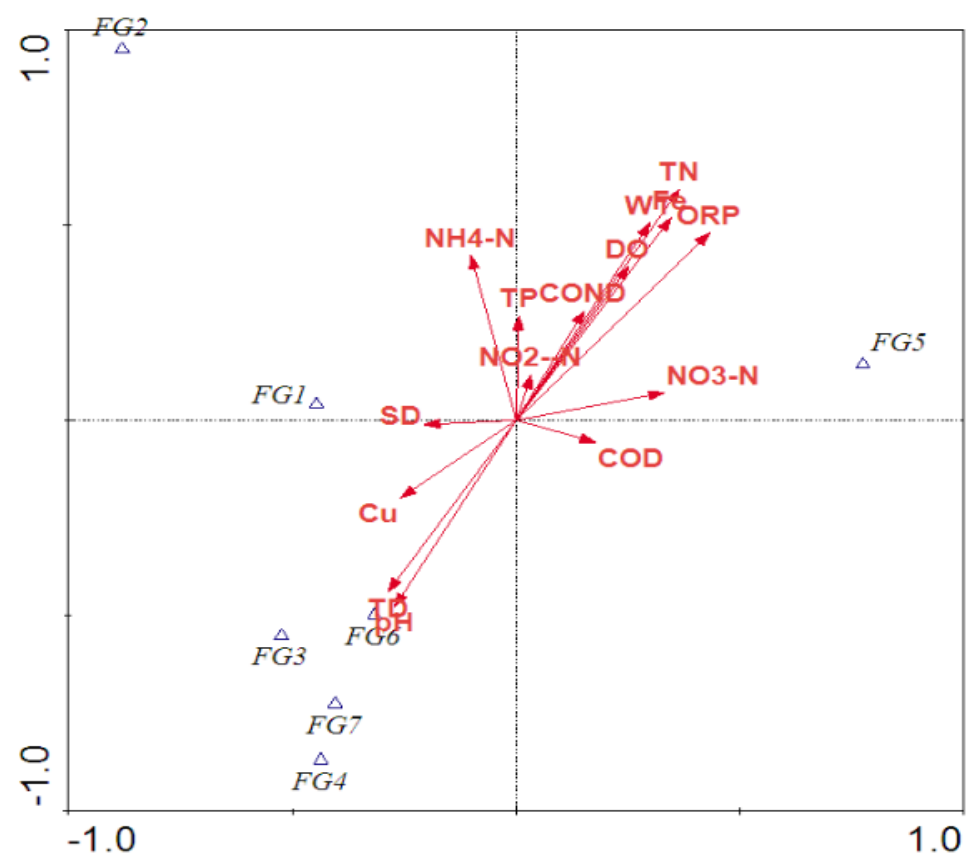

Figure 7. CCA tri-plot of fish functional groups and environmental factors in summer. Environmental factors: conductivity (COND), dissolved oxygen (DO), $p H$ value ( $p H)$, water temperature (WT), oxidation-reduction potential (ORP), total nitrogen (TN), total phosphorus $(\mathrm{TP})$, total dissolved solids $(\mathrm{TD})$, nitrate nitrogen $\left(\mathrm{NO}_{2}-\mathrm{N}\right)$, ammonium nitrogen $\left(\mathrm{NH}_{4}-\mathrm{N}\right)$, nitrate $\left(\mathrm{NO}_{3}-\mathrm{N}\right)$, chemical oxygen demand $(\mathrm{COD})$, dissolved iron $(\mathrm{Fe})$ and dissolved copper $(\mathrm{Cu})$ and water transparency (SD). Fish functional group: herbivores (FG1), insectivores (FG2), phytoplanktivores (FG3), zooplanktivores (FG4), benthivores (FG5), omnivores (FG6), piscivores (FG7)

In autumn (Fig. 8), WT and COD negatively correlated with axis 1 , while $\mathrm{pH}, \mathrm{NO}_{3}$ $\mathrm{N}, \mathrm{COND}$ and ORP positively with axis 2 . Meanwhile, SD, DO, Fe and TP negatively correlated with axis 2 . While, $\mathrm{Cu}, \mathrm{TN}, \mathrm{NO}_{2}-\mathrm{N}, \mathrm{NH}_{4}-\mathrm{N}$ and TD positively correlated with axis 2. The correlation between SD and Fe was weak. From the perspective of vector length, $\mathrm{NO}_{3}-\mathrm{N}, \mathrm{NO}_{2}-\mathrm{N}, \mathrm{Cu}$ and $\mathrm{DO}$ are the environmental factors that mainly affect the functional groups of the Muling River fish in autumn. Functional group FG3 and FG7 are distributed on the left side of axis 1 and above axis 2, mainly affected by WT and COD. FG2 is distributed on the upper side of axis 1 on the right side of axis 2, and is mainly affected by hydrological factors (COND, ORP) and nitrogen salt concentration $\left(\mathrm{NO}_{3}-\mathrm{N}, \mathrm{TN}\right), \mathrm{FG} 5$ is mainly affected by $\mathrm{Fe}$ and TP. The others are not greatly affected by water environmental factors. 


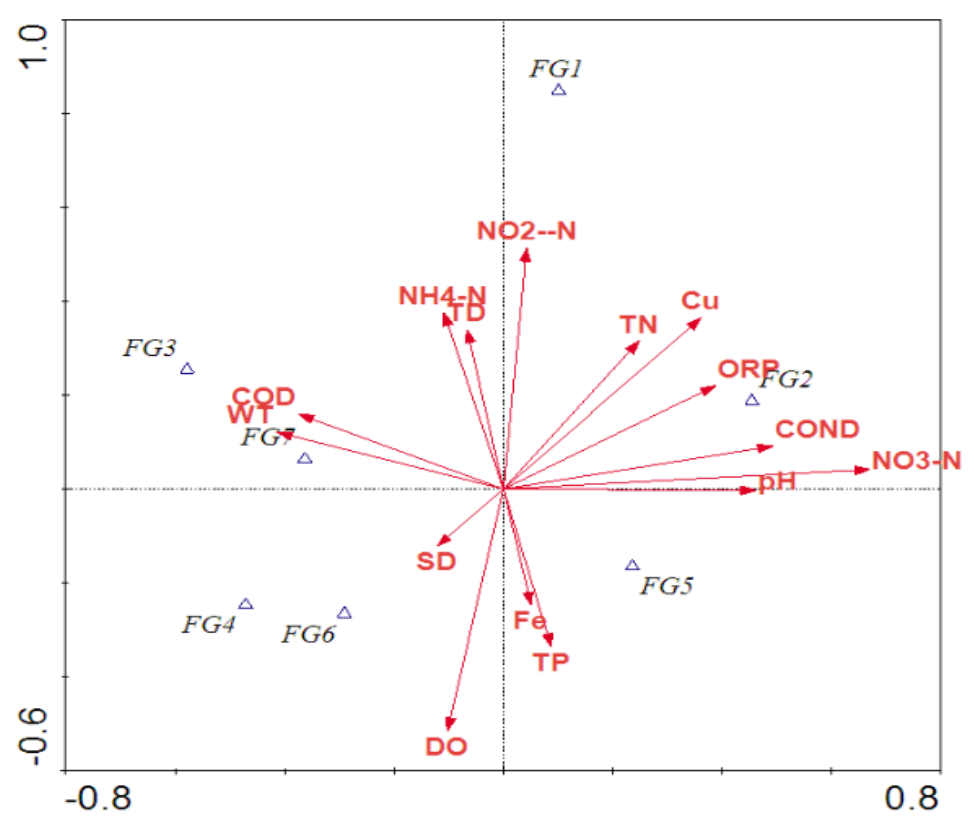

Figure 8. CCA tri-plot of fish functional groups and environmental factors in autumn. Environmental factors: conductivity (COND), dissolved oxygen (DO), $\mathrm{pH}$ value ( $\mathrm{pH})$, water temperature (WT), oxidation-reduction potential (ORP), total nitrogen (TN), total phosphorus $(T P)$, total dissolved solids $(T D)$, nitrate nitrogen $\left(\mathrm{NO}_{2}-\mathrm{N}\right)$, ammonium nitrogen $\left(\mathrm{NH}_{4}-\mathrm{N}\right)$, nitrate $\left(\mathrm{NO}_{3}-\mathrm{N}\right)$, chemical oxygen demand $(\mathrm{COD})$, dissolved iron $(\mathrm{Fe})$ and dissolved copper $(\mathrm{Cu})$ and water transparency (SD). Fish functional group: herbivores (FG1), insectivores (FG2), phytoplanktivores (FG3), zooplanktivores (FG4), benthivores (FG5), omnivores (FG6), piscivores (FG7)

\section{Discussion}

According to records, no relevant fish surveys have been conducted in the Muling River Basin, and the data available for reference is very limited. However, it is certain that due to external factors, the fish composition and distribution of the Muling River Basin have undergone obvious changes. Under the strong interference of human activities, the pressure of human activities has become an important factor affecting fish, which is reflected in the greater damage to the living environment of fish ( $\mathrm{Li}$ et al., 2012). The biological basis of fish bait, changes in fish community structure and biological characteristics all need in-depth investigation and research. Only a comprehensive investigation can formulate reasonable and effective protection measures. In addition, a monitoring system for fish and its ecological environment should be established to discover changes and development trends of the ecological environment in a timely manner through dynamic monitoring, understand the temporal and spatial laws of changes in the aquatic organisms' ecological environment in related areas, predict adverse trends and issue early warnings in time.

In a few areas of the Muling River Basin, fish resources have not been strictly managed, and random fishing still exists, and the use of nets is denser, which makes juvenile fish repeatedly caught and reduces the number of replenishments. With the growth of residents on both sides of the Muling River Basin in recent years, the catch has continued to increase. Illegal fishing activities such as electric fish poisoning have brought great damage to the fish resources of the Muling River Basin. In order to ensure 
the proliferation of fish resources, net meshes may be restricted to $10-15 \mathrm{~cm}$ in the future, the reproduction protection objects may be clearly defined, fishing licenses shall be implemented and fishing prohibited areas may be designated. It is hoped that the fishery department will strengthen management, resolutely implement the protection regulations and relevant laws and regulations, ban harmful fishing gear and fishing methods, and effectively protect juvenile fish resources (Liu and Cao, 1992). There are 44 water pollution sources in the basin, and the total wastewater discharge of key industrial enterprises is $30,501,600 \mathrm{~m}^{3} / \mathrm{a}$, accounting for $65.02 \%$ of the whole basin. Non-point source pollution occurred in the agricultural land, and a large amount of residual pesticides and fertilizers were lost to the river. Industrial enterprises along the Muling River Basin should strictly abide by the wastewater discharge indicators and do a good job of treatment before discharge. The abuse of pesticides and fertilizers is prohibited to reduce the amount of pesticides and fertilizers entering rivers in natural processes, and timely treatment measures should be taken for river sections with more serious pollution.

In the upper reaches of Muling River, there are Tuanjie Reservoir, Chengzi River Irrigation District, Liumao Irrigation District, Lishu Irrigation District and other water storage projects and irrigation projects. There are 27 dams in the whole water area. Due to changes in hydrological conditions, the habitats of some fish have been greatly reduced, such as benthic species (such as loach) that are accustomed to living in rapids. Not only will the original habitat be lost, but also the source of bait will be lost, which directly leads to the loss of some fish breeding conditions. The construction of water conservancy projects has reduced the living space of fish, which has led to a decrease in population and genetic diversity (Li and Xie, 2004; Yang et al., 2011). In order to coordinate the contradiction between the construction of water conservancy projects in the Muling River Basin and the protection of fish resources, and to make up for the damage caused to the fish habitat by the construction of water conservancy projects, according to the characteristics of different habitats in the upper, middle and lower reaches of the Muling River, suitable river sections should be selected to establish fish nature reserves to ensure that most fish will not become extinct, especially endemic species. The principle of nature reserves is to maintain the original natural appearance of the ecosystem. Therefore, water conservancy projects should not be built in the upper reaches of the rivers selected as nature reserves, and industrial and mining wastewater should be controlled to minimize the interference of human activities. Also, the ideological awareness of the protection of fish resources should further be strengthened for the managers of the protected area and the local residents, so that they can more deeply realize the importance of protection.

Fish functional groups are mainly classified according to their biological characteristics such as differences in feeding habits (Figuerola et al., 2012). By dividing functional groups, it is not only convenient to study the structure of fish communities, but also greatly simplifies the food web, which also opens up new ideas for scientific research (Bulman et al., 2001). The study of fish functional groups is mostly found in various sea areas. Hu et al. (2016) studied fish in the Qixing Islands Marine Special Reserve in Zhejiang Province, and Zhang et al. (2012) fish functional groups in the Bohai Sea and the East China Sea (Zhang et al., 2007). They also use the same functional species clusters to study the seasonal changes of fish, such as Li et al. (2014) on Laizhou Bay fish, and Lv et al. (2012) on the spring and autumn fish diversity in the Shandong waters of the Yellow Sea. The study of fish functional groups in freshwater 
river basins only found in rivers in the transitional region between the warm temperate zone and subtropical zone in the south (Yan, 2013) and lakes in subtropical regions (Wang, 2014). The Muling River is located in the northern alpine region. Compared with the ocean, the salinity and $\mathrm{pH}$ value of the water body are different, which leads to different plankton community composition (Chapman, 1973). The increase in the concentration of nutrient salts (nitrogen and phosphorus) in the water body will promote the synthesis of chlorophyll a, and the density of phytoplankton will increase, thereby promoting the growth of zooplankton ( $\mathrm{Li}$ and $\mathrm{Yu}, 2002)$, which will directly affect the phytoplankton feeding functional groups of fish and phytoplankton. Feeding functional group of zooplankton fish.

The development of cold-water fish farming in the corresponding section of the Muling River has great resource potential, and it is possible to select and breed chickfish and tequila as the main economic fish for promotion. Both fish are suitable for breeding in cold spring water and mountain streams. In rich areas, the prospects for artificial breeding are promising (Cheng, 2015). While protecting fish resources, it can also increase people's income and improve people's livelihood. Artificial reproduction and release are common practices in countries all over the world to restore fish resources. It can supplement the size of fish populations and reserve a sufficient number of broodstock reserve groups. It can also preserve fish germplasm resources and maintain the species diversity of local indigenous fish (Yang et al., 2013). It is recommended that artificial breeding and releasing stations be established in suitable sections of the Muling River Basin, and artificial reproduction and releasing can be carried out in a planned way. While promoting the recovery of fish species, it can also increase fishery resources and increase residents' income.

\section{Conclusion}

A total of 22 species of fish caught in the Muling River Basin were identified in this investigation, belonging to 4 orders, 5 families and 16 genera. The three fish diversity indices do not fluctuate greatly with the seasons throughout the year, and their changing trends are roughly the same. It can be seen that the fish species of the Muling River are relatively stable. The fish caught in the Muling River are mainly divided into seven types of functional groups. The environmental factors affecting the functional groups of fish are slightly different from season to season. Spring is TN, $\mathrm{pH}, \mathrm{ORP}, \mathrm{SD}, \mathrm{COND}$, summer is TN, pH, Fe, ORP, WT, TD, and autumn is the same as summer. These environmental factors should be taken into account for future fish population restoration.

Acknowledgements. The study was supported by the central government supports the reform and development fund projects of local colleges and universities "Research on integrated technology innovation of sustainable utilization of cold water fish resources industrialization" (2020GSP14), and Key research topics of economic and social development in Heilongjiang Province (20309), and the major special projects of science and technology in Liaoning Province (2020JH1/10200002), Dalian Science and Technology Innovation Fund Project (2019J12SN64), and Agricultural finance special project "Investigation of fishery resources and environment in key waters of Northeast China". 


\section{REFERENCES}

[1] Bulman, C., Althaus, F., He, X., Bax, N. J., Williams, A. (2001): Diets and trophic guilds of demersal fishes of the southeastern Australian shelf. - Marine and Freshwater Research 52: 537-548.

[2] Chapman, D. J. (1973): Biliproteins and bile pigments. - London: Blackwell Scientific Publications.

[3] Chen, Y. Y. (1990): Several biodiversity issues in freshwater ecosystems. - Chinese Bulletin of Life Sciences 5: 197-200. (in Chinese with English abstract).

[4] Chen, X. J. (2014): Impacts of operation of hydropower projects on aquatic organisms and mitigation measures. - Yangtze River 15: 7-13. (in Chinese with English abstract).

[5] Cheng, Z. Y. (2015): Species and prospects of cold-water fish breeding in Heilongjiang Province. - Northern Chinese Fisheries 6: 9-11. (in Chinese).

[6] Ding, B. Q., Liu, H. Z. (2011): Analysis of fish feeding guild composition in the Yangtze River. - Sichuan Journal of Zoology 1: 31-35. (in Chinese with English abstract).

[7] Figuerola, B., Maceda-Veiga, A., De, S. A. (2012): Assessing the effects of sewage effluents in a Mediterranean creek: fish population features and biotic indices. Hydrobiologia 694(1): 75-86.

[8] Giles, N., Sands, R., Fasham, M. (2005): Fish. - In: Hill, D., Fasham, M., Tucker, G., Shewry, M., Shaw, P. (eds.) Handbook of Biodiversity Methods: Survey, Evaluation and Monitoring. Cambridge University Press, Cambridge, pp. 368-386.

[9] Holmlund, C. M., Hammer, M. (1999): Ecosystem services generated by fish populations. - Ecological Economic 29: 253-268.

[10] Hu, C. Y., Shui, Y. Y., Tian, K., Li, L., Qin, H. L., Zhang, C. C., Ji, M. M., Shui, B. N. (2016): Functional group classification and niche identification of major fish species in the Qixing Islands Marine Reserve, Zhejiang Province. - Biodiversity Science 2: 175184. (in Chinese with English abstract).

[11] Karr, J. R. (1981): Assessment of biotic integrity using fish communities. - Fisheries 6: 21-27.

[12] Li, G. G., Yu, Z. M. (2002): Community Structure of Zooplankton in Lake Qiandaohu. Acta Ecologica Sinica 22(2): 156-162. (in Chinese with English abstract).

[13] Li, H. J., Xie, C. X. (2004): Fauna Composition and Resources Protection of Freshwater Fish in Forest Streams in the Central North of Guangxi Province. - Journal of Northeast Forestry University 32(1): 89-92. (in Chinese with English abstract).

[14] Li, J., Li, X. H., Jia, X. P., Tan, X. C., Wang, C., Li, Y. F., Shao, X. F. (2012): Relationship between fish community diversity and environmental factors in the Lianjiang River, Guangdong, China. - Acta Ecologica Sinica 18: 5795-5805. (in Chinese with English abstract).

[15] Li, F., Xu, B. Q., Ma, Y. Q., Lv, Z. B., Wang, T. T. (2014): Seasonal changes of functional guilds of fish community in Laizhou Bay, East China. - Acta Ecologica Sinica 34(7): 1736-1745. (in Chinese with English abstract).

[16] Liu, J. K., Cao, W. X. (1992): Fish resources of the Yangtze River basin and the tactics for their conservation. - Resources and Environment in the Yangtze Valley 1(1): 17-23. (in Chinese with English abstract).

[17] Liu, H. Z., Yang, J. X., Liu, S. W., Gao, X., Chen, Y. S., Zhang, C. G., Zhao, K., Li, X. H., Liu, W. (2016): Theory and methods on fish diversity monitoring with an introduction to the inland water fish diversity observation in China. - Biodiversity Science 11: 12271233. (in Chinese with English abstract).

[18] Lv, Z. B., Li, F., Xu, B. Q., Wang, B. (2012): Fish community diversity during spring and autumn in the Yellow Sea off the coast of Shandong. - Biodiversity Science 20(2): 207214. (in Chinese with English abstract).

[19] Ma, K. P. (1994): Methods of Measuring the Diversity of Biological Community. Chinese Biodiversity 2(3): 162-168. (in Chinese with English abstract). 
[20] Mao, Z. G., Gu, X. H., Zeng, Q. F. (2016): The structure of fish community and changes of fishery resources in Lake Hulun. - Journal of Lake Science 2: 387-394. (in Chinese with English abstract).

[21] MEP. (2002): Water and Wastewater Monitoring Method (Fourth Edition). - Beijing: China Environmental Science Press. (in Chinese).

[22] Sarkar, U. K., Pathak, A. K., Sinha, R. K., Sivakumar, K., Pandian, A. K., Pandey, A., Dubey, V. K., Lakra, W. S. (2012): Freshwater fish biodiversity in the River Ganga (India): changing pattern, threats and conservation perspectives. - Reviews in Fish Biology and Fisheries 22: 251-272.

[23] Shi, R. D., Wu, Z. Q., Huang, L. L., Feng, W. L., Zhu, Z. J., Ding, Y., Hu, Y. X. (2015): Fish species diversity of the upper Xiangjiang River in North Guangxi Province. Journal of Guangxi Normal University: Natural Science Edition 4: 127-136. (in Chinese with English abstract).

[24] Simon, T. P. (1999): Assessing the sustainability and biological integrity of water resources using fish communities. - New York: CRC Press 6-7.

[25] Wang, S. B., Song, Z., Li, P. (2006): Current situation of China fishery resources and countermeasures for the sustainable development. - Chinese Fisheries Economics 1: 2427. (in Chinese with English abstract).

[26] Wang, W. J. (2014): Spatial pattern in the structure and diversity of the taxonomic and functional organizations of stream fish in the mountains of southern Anhui. - Anhui Normal University. (in Chinese with English abstract).

[27] Xia, J. H., Lu, J. F., Zhou, B. C., Tan, H. Z. (2009): A preliminary study on fish communities in Suzhou Creek, Shanghai. - Journal of Lake Sciences 04: 538-546. (in Chinese with English abstract).

[28] Xiao, Q., Yang, Z., Tang, H. Y., Duan, P. X., Wang, X. Q., Xiao, T. Y., Liu, X. Y. (2015): Species diversity of fish and its conservation in the mainstream of the lower reaches of Wu River. - Biodiversity Science 4: 499-506. (in Chinese with English abstract).

[29] Yan, L. L. (2013): Longitudinal patterns in taxonomic and functional organizations of fish assemblages of the headwater streams within the Qingyi River. - Anhui Normal University. (in Chinese with English abstract).

[30] Yang, Y. H., Yang, J. X., Pan, X. B., Zhou, W., Yang, M. L. (2011): Fishery resource protection by artificial propagation in hydroelectric development: Lixianjiang River drainage in Yunnan as an example. - Zoological Research 32(2): 188-195. (in Chinese with English abstract).

[31] Yang, C. Y. (2012): Diversity of fishery resources of the Yuanshui River. - Central South University of Forestry \& Technology 48-56. (in Chinese with English abstract).

[32] Yang, J. X., Pan, X. B., Chen, X. Y., Wang, X. A., Zhao, Y. P., Li, J. Y., Li, Z. Y. (2013): Overview of the artificial enhancement and release of endemic freshwater fish in China.Zoological Research 34(4): 267-280. (in Chinese with English abstract).

[33] Zhang, J. M., He, Z. H. (1993): Neilu Shuiyu Yuye Ziran Ziyuan Shouce. - Beijing: Science Press. (in Chinese).

[34] Zhang, J. M. (1995): Fish History of Heilongjiang Province. - Harbin: Heilongjiang Science and Technology Press. (in Chinese).

[35] Zhang, B., Tang, Q. S., Jin, X. S. (2007): Functional groups of fish assemblages and their major species at high trophic level in the East China Sea. - Journal of Fishery Science of China 6: 939-949. (in Chinese with English abstract).

[36] Zhang, B., Li, Z. Y., Jin, X. S. (2012): Functional groups of fish assemblages and their major species in the Bohai Sea. - Journal of Fisheries of China 1: 64-72. (in Chinese with English abstract). 